INTERDISCIPLINARIA ARCHAEOLOGICA NATURAL SCIENCES IN ARCHAEOLOGY

\title{
Cocklebur (Xanthium strumarium L.) in the Archaeological Chronicle of Ukraine
}

\author{
Sergiy Gorbanenko ${ }^{a^{*}}$ \\ ${ }^{a}$ The Institute of Archaeology of the National Academy of Sciences of Ukraine, Heroiv Stalingrada 12 ave., 04210, Kyiv, Ukraine
}

\section{ARTICLE INFO}

\section{Article history:}

Received: $9^{\text {th }}$ May 2020

Accepted: $29^{\text {th }}$ September 2020

DOI: http://dx.doi.org/10.24916/iansa.2020.2.3

\section{Keywords:}

archaeology

palaeoethnobotany

Ukraine

Eastern Europe

common cocklebur

Xanthium strumarium L.

Scythians

Slavs

\begin{abstract}
A B S TRACT
This article collects and organizes data on common cocklebur (Xanthium strumarium L.) finds from archaeological sites in modern Ukraine. The first find comes from charred macro-residues discovered in the middle of the $20^{\text {th }}$ century in the hillfort of Bilsk. Two more finds are represented by imprints on clay products. They were discovered as a result of a purposeful inspection of ceramics; these finds come from Scythian sites. The last find comes from an Ancient Rus site: a significant amount of charred material was found there.

The territory of modern Ukraine is situated at the crossroads of Eurasian land routes and waterways. The findings presented are important for restoring the history of the appearance of the cocklebur in Europe.
\end{abstract}

\section{Introduction}

Scientists who study the distribution of plants in time and space usually encounter difficulties related to the insufficient content of existing information databases on this subject. Such an invasive plant as the common cocklebur (Xanthium strumarium L.) is no exception. It is an annual late weed growing in fields, pastures, gardens, ravines and near dwellings, mainly on sandy soils. It is now widespread throughout Ukraine (Veselovskii, Lysenko and Manko, 1988, p.60).

For a long time, the question of the appearance of cocklebur in the territory of modern Ukraine was unsettled. Thus, back in the 1980s, V.V. Protopopova only indicated that the routes of its spreading to Europe were apparently related to nomadic tribes, such as the Goths, Huns, Pechenegs, Polovtsians (Cumans), Tatars, etc. Based on the archaeological sources available at that time, the researcher indicated the period of its appearance in Europe as the

*Corresponding author. E-mail: gorbanenko@gmail.com
Medieval period (Protopopova, 1989, pp.78-80). Given the lack of evidence, this assumption, although likely, is less important than determining the route of its entry: namely, following the ways of the nomads from Central Asia.

Recently, an article with an analysis of palaeoethnobotanical materials from the Lutomiersk-Koziówki settlement near Łódź (Central Poland) has been published (Mueller-Bieniek et al., 2015, pp.280-281). We will give more detailed attention to the section of this article relating to cocklebur (X. strumarium L.) since the authors' fairly comprehensive review and analysis deprive us of the need to conduct such an inspection on our own. The main theses are as follows. 1) Since pollen can be transported over long distances together with the wind, it is important to find macro-residues of cocklebur. 2) In the settlement of Lutomiersk-Koziówki, the oldest finds of macroresidues of cocklebur in Europe have been discovered: the archaeological period is the Late Bronze Age (HaB1-HaB2). The date by radiocarbon analysis is $2745 \pm 30 \mathrm{BP}$, therefore after calibration this is $912-841 \mathrm{BC}$ cal with a probability of $68.2 \%$ (975-818 BC has a probability of $95.4 \%) .3$ ) In Europe, the oldest finds of macro-residues are known in the 


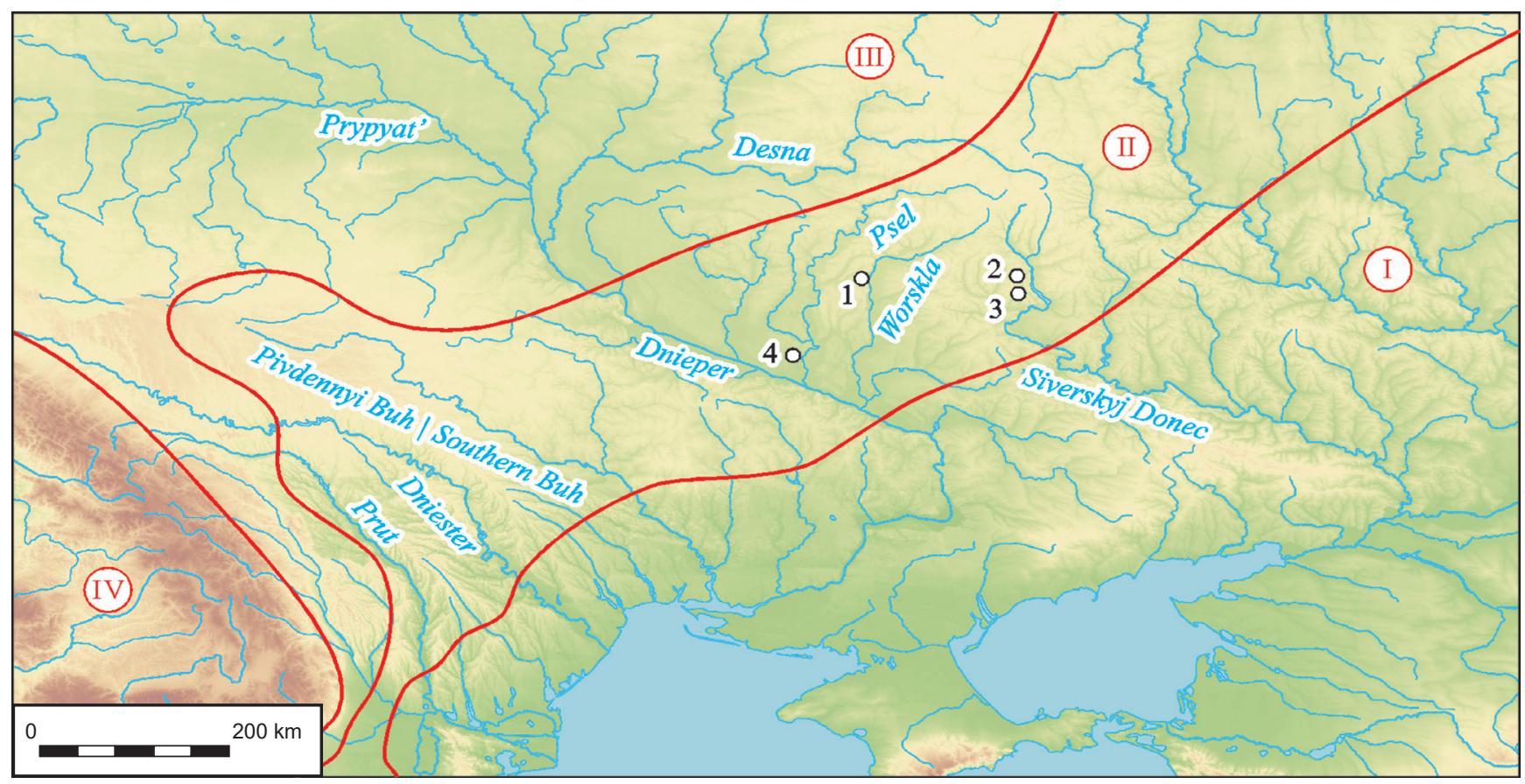

Figure 1. Map of cocklebur finds in the territory of modern Ukraine: Scythian sites: 1 - Bilsk; 2 - Tsyrkuny; 3 - Novoselivka; Ancient Rus site: 4 - Manzhelia (I - steppe zone; II - forest-steppe zone; III - forest zone; IV - the regions of altitudinal zonality, after Arepeva et al., 1974, p.24).

settlements of the Late Bronze Age and mainly of the Early Iron Age; however, the greatest number of such finds relates to the Middle Ages. 4) A cocklebur is an archaeophyte that has come to Europe from the East. 5) The authors have made an overview of the cocklebur plant in antiquity in Europe and concluded that it was just the species $X$. strumarium L. (Mueller-Bieniek et al., 2015, pp.280-281).

\section{Materials and methods}

The study was carried out in several stages. During palaeoethnobotanical studies of imprints on clay products, two imprints from two sites of Scythian times were found. According to the results of the study of charred macroresidues from the ancient Rus hillfort, several dozen whole and fragmented burnt fruits were identified. Acquaintance with academic literature led to an understanding of a certain uniqueness with such finds. A study of the special literature on the palaeoethnobotany of Ukrainian archaeological sites allowed only one more case of the finding of a fragment of a charred fruit in an early Iron Age site to be detected.

Thus, the material was obtained in two ways: taking imprints from clay products in two cases, and the accidental detection of charred macro-residues in two cases. Three out of the four cases have occurred in recent years.

Below is a catalogue of the finds of common cocklebur in the archaeological sites of Ukraine. The material is given in chronological order from the earliest find. The sites, where cocklebur was found are represented in the map (Figure 1) ${ }^{1}$.

\footnotetext{
The numbering in the catalog and on the map is the same.
}

\section{Results}

\subsection{Bilske hillfort (Poltava Region)}

Western fortification, ash heap 19. The research was carried out in 1967-1968 by a Scythian-Slavic archaeological expedition of A.M. Gorky Kharkiv State University (now V. N. Karazin Kharkiv National University) led by B.A. Shramko. The material was archaeologically dated back to the second half of the seventh century BC (Shramko, 1971; Šramko, 1973, pp.154-157). Accumulations of charred palaeoethnobotanical material in pits 1 and 3 were found; it was an accidental find. A fragment of the cocklebur fruit was found in the sample from pit 3 (No 508/19-68). The identification was made by the staff of the All-Union Institute of Plant Breeding: M.M. Yakubtsiner, R.Kh. Makasheva, M.V. Lukianova, V.N. Lysova, R.A. Udachina (Šramko 1973, pp.54-157).

\subsection{Tsyrkuny hillfort (Kharkiv Region)}

Early Iron Age. The study was undertaken by the Tsyrkuny archaeological expedition of Kharkiv Historical Museum under the direction of K.Yu. Peliashenko in the period 2007-2017. The material was archaeologically dated from the end of the fifth to the fourth century BC (e.g. Peliashenko, 2017). Clay products from the excavations were inspected and one imprint on the fragment of a pot was found. Another indentation nearby is somewhat reminiscent of an identified imprint. However, it is unclear and has no characteristic depressions from the spines (Figure 2:1). Identification was made by S.A. Gorbanenko (Gorbanenko, 2019, p.364). The collection is stored in the depository of the Museum of Archeology of V.N. Karazin KhNU and in the M.F. Sumtsov Kharkiv Historical Museum. 

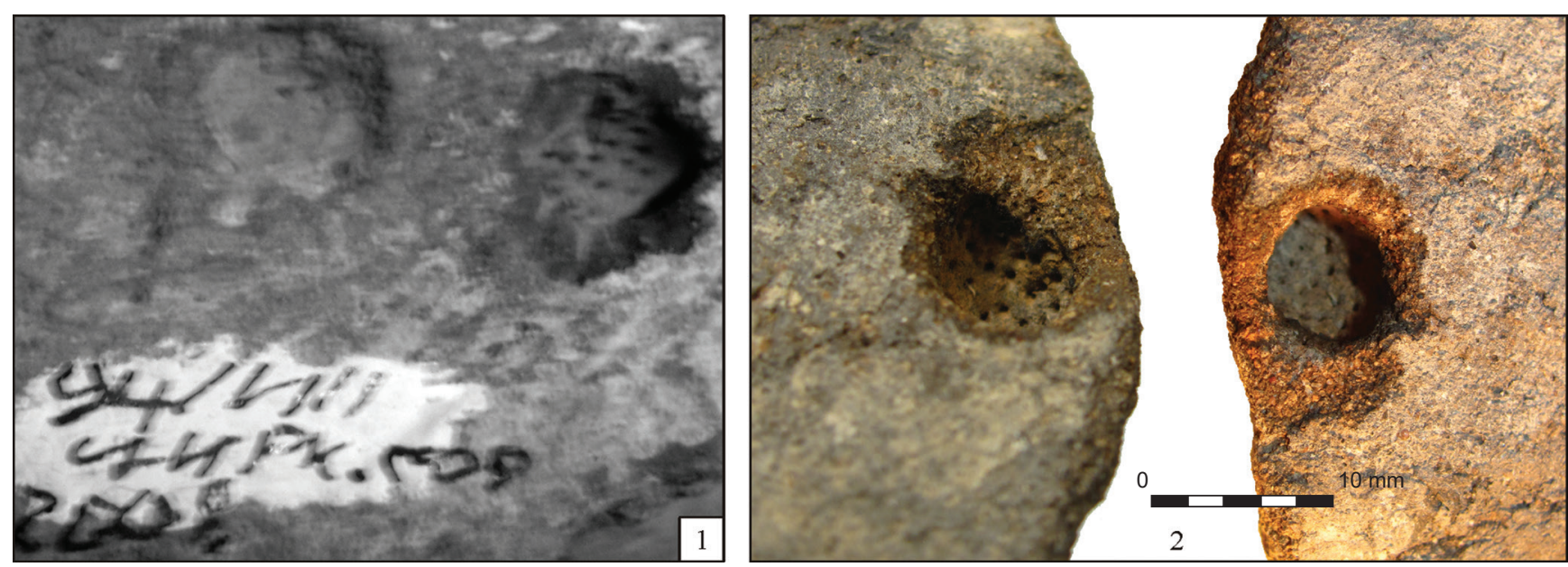

Figure 2. Cocklebur from the Scythian sites, imprints on pots: 1 - Tsyrkuny (approximately double size; photo by S.A. Gorbanenko); 2 - Novoselivka (photo by S.A. Zadnikov).

\subsection{Novoselivka settlement (Kharkiv Region)}

Early Iron Age. The study was conducted by an expedition of the State enterprise of the Security Archaeological Service of Ukraine "Slobozhansk Archaeological Service" under the direction of I.B. Shramko in 2010-2012. The material was archaeologically dated to the fourth century BC (Shramko, 2011; Shramko, Peliashenko, Zadnikov, 2012). Clay products from the excavations were inspected and an imprint on a fragment of a pot was found (Figure 2:2). Identification was made by S.A. Gorbanenko. The collection is stored in the depositary of the Museum of Archaeology of V. N. Karazin KhNU.

\subsection{Manzhelia hillfort (Poltava Region)}

Ancient Rus period. The excavation was carried out by an expedition of the Centre for Protection and Research of Monuments of Archaeology of the Department of Culture of Poltava Regional State Administration under the direction of V.V. Sherstiuk in 2015-2016. The remains of a residential structure archaeologically dated from the middle to the second half of the twelfth century AD were investigated (Sherstiuk, 2018; Gorbanenko and Sherstiuk, 2017). Classical archaeological methods (selection by hand) allowed a significant amount of botanical materials to be collected. The materials were in several accumulations. One of them consisted of several dozens of whole and fragmented charred fruits of cocklebur (Figure 3) $)^{2}$.

\section{Discussion}

The territory of modern Ukraine is situated at the crossroads of many land routes and waterways connecting Europe and Asia. The waterway "from the Varangians to the Greeks"

\footnotetext{
${ }^{2}$ In the field, the material was pre-determined by the head of the expedition V.V. Sherstyuk. Scientific examination after the photo, which confirmed the previous observations, was conducted by H.O. Pashkevych.
}

passed through this area (in a north-south direction) as well as partially the path of permanent migrations from Asia to Europe (the segment through eastern Europe to its central and western part, Figure 4). It is important to add here that nomads chose for migration the natural conditions familiar to them, such as steppe areas, and protrusions of steppe areas, that rose into the forest-steppe zone along the river valleys. All the sites where the data on cocklebur came from were located in the forest-steppe zone (see Figure 1).

According to the available materials from Ukraine, the first finds of common cocklebur came from Scythian sites. For a long time, there has been no discussion on the migration waves of the early nomads that was occurring throughout the whole Early Iron Age (e.g. Alekseev, 2003; Bruiako, 2005; historiography of the issue $-i d$ ). Thus, the data suggest that at least at the beginning of the Early Iron Age, the common cocklebur had already reached the territory of modern Ukraine. Given the eventuality of palaeoethnobotanical studies in general, as well as in Ukraine, the randomness of such findings is extremely low. Thus, as of 1991, materials from only 17 sites of the Bronze Age had been analysed. The vast majority of them were small samples of imprints on clay products. Only one mass-find of charred macro-residues contained a significant number of specimens of weeds (see Pashkevich, 1991). The state of research of the sites of this period has not changed significantly since then.

Thus, today we can only speak about the earlier appearance of common cocklebur in the territory of modern Ukraine hypothetically: only on the basis that in the territories to the west it was discovered on Bronze Age sites. Further targeted exploration and research could shed light on this issue.

According to materials from Scythian sites (the Early Iron Age), it is difficult to say something about the use of the cocklebur. Materials from Manzhelia are the best sample; they therefore should be discussed in more detail.

It should be recalled that the dwelling of Ancient Rus time was investigated in Manzhelia. By all indications, it was destroyed in a fire. A detailed comparison of the 

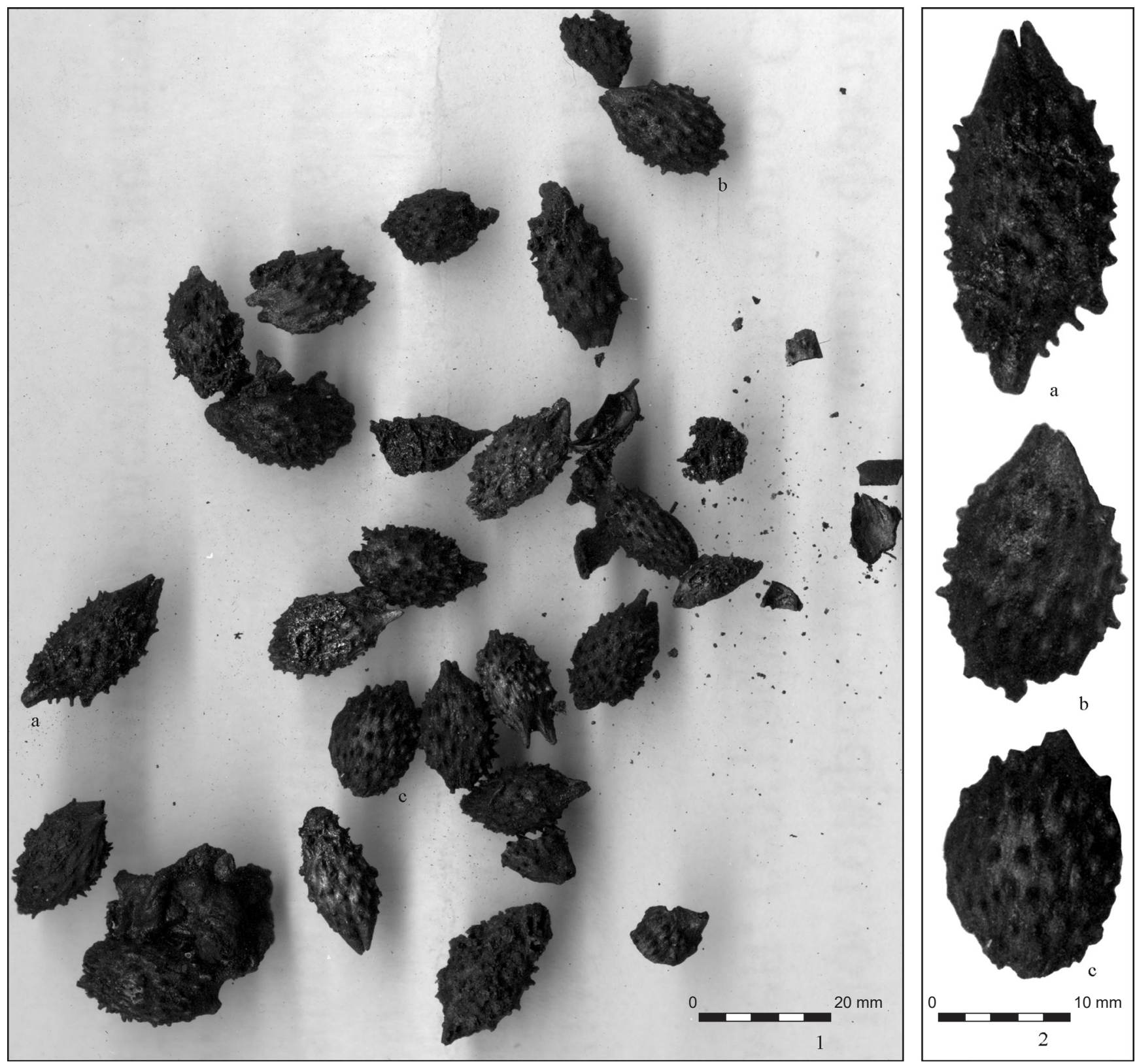

Figure 3. Cocklebur from the Ancient Rus hillfort of Manzhelia: 1 - general view; 2 - some examples of fruits in detail.

palaeoethnobotanical materials found in this structure even made it possible to speculate about the probable time of year of its destruction. It happened in late summer (or early autumn): most likely in August (see Gorbanenko and Sherstiuk, 2017, pp.149-150). In addition to cocklebur, crop grain was also found in the house: rye (Secale cereale) and millet (Panicum miliaceum). Also found were: legumes - pea (Pisum sativum); weeds - flowers of the Aster family(Asteraceae) - probably calendula (Calendula sp. $)^{3}$; fruit stones of trees of the Prunus genus - cherry (Prunus subg. Cerasus) and plum (Prunus sp.). Finds of cultivated plants are not of particular interest; however, the remnants of the fruits of trees and weeds do attract attention. Thus, the find

\footnotetext{
Consultation was provided by O.Yu. Lebedeva.
}

of cherry and plum stones indicate gardening or gathering. Gathering is also indicated by the finds of the fruits of common cocklebur, and probably of calendula flowers, though the latter are relatively few, no doubt primarily due to their fragility. However, there were several dozens of cocklebur fruits. This indicates a targeted, rather than just accidental, appearance of these plant parts in the dwelling. Both of these plants have healing properties; they are still used in traditional medicine (Chopik, Dudchenko and Krasnova, 1983). So, for the Ancient Rus period, we can assume the following about the cocklebur: 1) people of ancient Rus were already familiar with the healing properties of the common cocklebur; and 2) the cocklebur was distributed in such quantities that made it possible to be harvested as a medicinal plant. 
Figure 4. Schematic map of Europe and the direction of land migrations of nomads.

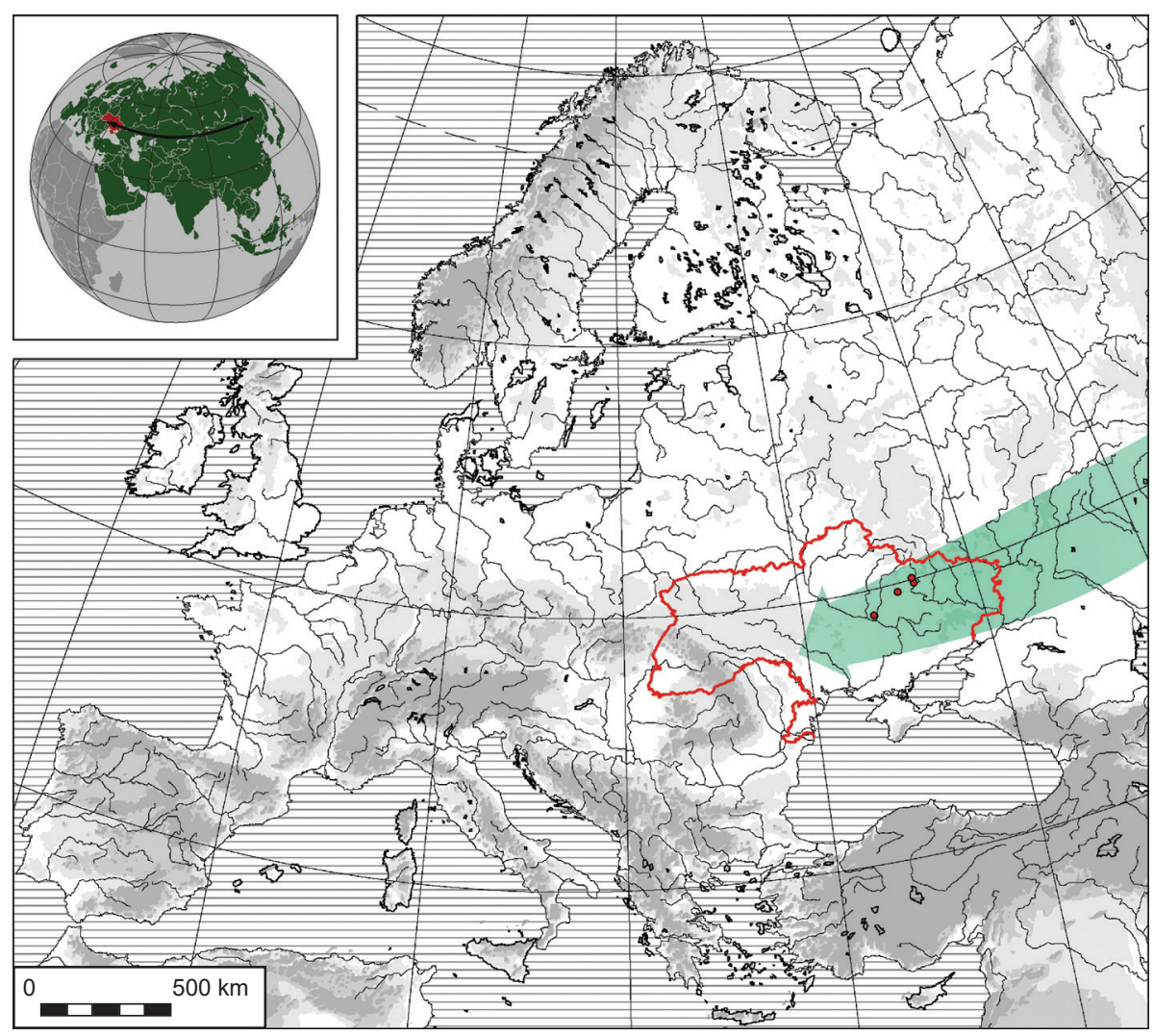

\section{Final provisions}

The following circumstances prompted me to write this article: Firstly, over a relatively short period of time, material indicative of the rather early appearance of the common cocklebur in the territory of modern Ukraine has been accumulated. However, since I am not a botanist by profession, I considered it necessary to share these data with specialists who may require such information. Secondly, the publication of this material at least partially 'closes' the geographical lacuna in the distribution of this species in ancient times on its way from the east - from Asia, to central and western Europe. The appearance of this publication has been facilitated by a familiarization with the content of an article on the analysis of paleoethnobotanical materials from the settlement of Lutomiersk-Koziówki near Łódź in Central Poland (Mueller-Bieniek et al., 2015), which could indicate that prehistoric contacts between East and West shifted to the north of the Carpathian Belt.

\section{Conclusions}

At least three Scythian sites where common cocklebur has been found are known today, thus eliminating the somewhat randomness of discovered and identified material existing previously. The penetration of the plant into the territory of modern Ukraine should be dated no later than the beginning of the Early Iron Age. For the period of Ancient Rus, we are now able to raise the issue of the collection and use of this plant for medicinal use.

\section{Acknowledgment}

I am grateful to Yu.V. Boltrik, S.A. Zadnikov, O.Yu. Lebedeva, H.O. Pashkevych, K.Yu. Peliashenko, V.V. Sherstiuk and I.B. Shramko for contributing to the publication of this article, as well as to the reviewers for significant comments to improve the structure of the study. The article was translated by Maryna Sergeeva.

\section{References}

ALEKSEEV, A.Yu., 2003. Khronografiia Evropeiskoi Skifii VII-IV vekov do n. e. Sankt-Peterburg: Gosudarstvennyi Ermitazh.

AREPEVA, N.I., BURAKOVA, M.A., KACHALINA, N.M., MAKHROVA, K.I., PEKHOVA, Z.P. et al., 1974. Uchebnyi atlas mira, $2^{\text {nd }}$ edition. Moskva: Glavnoe upravlenie geodezii i kartografii pri Sovete ministrov SSSR.

BRUIAKO, I.V., 2005. Rannie kochevniki v Evrope ( $X-V$ vv. do R. Kh.). Arkheologicheskie istochniki Vostochnoi Evropy. Kishinev: Vysshaia antropologicheskaia shkola.

CHOPIK, V.I., DUDCHENKO, L.G., KRASNOVA, A.N., 1983. Dikorastushchie poleznye rasteniia Ukrainy. Spravochnik. Kiev: Naukova dumka.

GORBANENKO, S., 2019. Paleoetnobotanichni vyznachennia 2017 r. Arkheolohichni doslidzhennia v Ukraini 2017 r., 362-371.

GORBANENKO, S.A., SHERSTIUK, V.V., 2017. Roslynnyi ratsion davnoruskoi rodyny z Manzhelii. In: O.P. Motsia, ed. Vozviahl-ZviahelNovohrad-Volynskyi u chasovomu zrizi tysiacholit. Kharkiv: Maidan, Kyiv: Starodavnii svit, pp. 146-151. 
MUElleR-BIENIEK, A., KITTEL, P., MuzOlf, B., MUZOLF, P., 2015. Useful plants from the site Koziówki near Łódź (central Poland) with special reference to the earliest find of Xanthium strumarium L. seeds in Europe. Journal of Archaeological Science: Reports, 3, 275 284. doi: http://dx.doi.org/10.1016/j.jasrep.2015.06.025.

PASHKEVICH, G.A., 1991. Paleoetnobotanicheskie nakhodki na territorii Ukrainy (neolit-bronza): Katalog. Kiev: Preprint.

PELIASHENKO, K.Iu., 2017. Zolnik Tsirkunovskogo gorodishcha. Arkheolohiia i davnia istoriia Ukrainy, 2(23): Starozhytnosti rannoho zaliznoho viku, 340-353.

PROTOPOPOVA, V.V., 1989. Roslyny-mandrivnyky. Kyiv: Radianska shkola.

SHERSTIUK, V.V., 2018. Rozkopky na terytorii Manzheliivskoho horodyshcha na Poltavshchyni. Arkheolohichni doslidzhennia v Ukraini $2016 r$., 205-207.
SHRAMKO, B.A., 1971. Issledovanie Belskogo gorodishcha. Arkheologicheskie issledovaniia na Ukraine 1968, 3, 49-58.

ŠRAMKO, B.A., 1973. Der Ackerbau bei den Stämmen Skythiens im 7-3. Jahrhundert v. u. Z. Slovenská archeológia, 21(1), 147-167.

SHRAMKO, I.B., 2011. Okhrannye issledovaniia poseleniia skifskogo vremeni u s. Novoselovka. Arkheolohichni doslidzhennia v Ukraini $2010 r .376-377$.

SHRAMKO, I.B., PELIASHENKO, K.Iu., ZADNIKOV, S.A., 2012. Okhrannye raskopki poseleniia skifskogo vremeni u s. Novoselovka. Arkheolohichni doslidzhennia v Ukraini 2011 r., 446-447.

VESELOVSKII, I.V., LYSENKO, A.K., MANKO, Yu.P., 1988. Atlasvyznachnyk bur'ianiv. Kyiv: Urozhai. 